\title{
Hr Management System Based On Competency and Assessment Of Work Achievement and Its Effects On Device Performance Of Batubulan Village Office
}

\author{
Ni Made Yudhaningsih ${ }^{1}$, Ni Wayan Ari Sudiartini ${ }^{2}$ \\ \{nimadeyudha@gmail.com ${ }^{1}$,wayan.ari1987@gmail.com ${ }^{2}$ \} \\ Faculty of Economics, Mahendradatta University, Denpasar, Bali ${ }^{1,2}$
}

\begin{abstract}
According to the mandate of Law no. 6 of 2014, the village has a function of implementing rural development to improve the welfare and quality of life of rural communities. But in terms of performance of human resources is often still not optimal. This study aims to determine competency-based human resource management and work performance on village officials' performance. This study's results are competency-based human resource management, and work performance has a positive and significant effect on village officials' performance and either partially or simultaneously. The population in this study were village officials in the village of Batubulan. This research uses quantitative methods. Primary data is taken using a questionnaire instrument. This study's results are expected to provide solutions to improve village officials' performance in Batubulan Village, Sukawati Gianyar, Bali.
\end{abstract}

Keywords: Performance, Competency-based HR, job performance appraisal.

\section{Introduction}

Governance village is a unit smallest inside national, governance administration system village have authority to organize and manage the community's interests. Government villages received strict attention in fostering society villages to achieve the government's goal of developing Indonesia from the periphery by strengthening regions and villages within a unitary state framework. Apart from being supported by an adequate budget, advancing village development must also be supported by qualified human resources to achieve goals. Batubulan Village is one of the villages as a destination for domestic, international tourism destinations and local tourism. To flourish and always exist as a tourist village expected role of village officials to Dapat organize and manage society's interests in terms of infrastructure, community development, and the field of public administration services. However, it is still inadequate for Human Resources (HR), especially village government officials who will carry out rural development programs through the Village Fund Budget (ADD) from the District government and Village Funds provided directly by the central government. In the context of regional staffing, the low performance of Regional Government employees is not new [1]

Performance is the result of work in quality and quantity achieved by an employee in carrying out his duties under the responsibilities assigned to him [2]. A sound performance management system consists of identifying, encouraging, improving, and rewarding employee performance. Performance is measured by how much the employee contributes to the company Mundiarti (2007) with indicators: Number of work done, quality of work, timeliness, 
presence of cooperation [3].

According to Armstrong and Baron inside Wibowo (2007: 99) [4], factors that affect performance is a personal factor which is determined by skill level, competence owned by individuals. Competence is one of the factors that affect employee performance. According to Spencer and Spencer (1993), competence is a characteristic that underlies a person related to the standard of practical and superior performance criteria at work in certain situations [5]. Competence describes the level of knowledge, skills, and behavior employees have in carrying out their duties effectively and efficiently. Competence in this study will use indicators that include cognitive competence, social competence, and emotional competence, which are the basis of theory testing [6]. Another variable that can affect performance is job performance appraisal. Job performance appraisal is a system used to assess and determine whether an employee has carried out their respective jobs as a whole.

In this case, the implementation of work does not mean that it is only seen/assessed by physical results. Still, it includes various things such as the quantity of work, quality of work, discipline, cooperation, responsibility, loyalty, honesty, and loyalty [7]. According to Hasibuan (2000), job performance appraisal is a systematic evaluation of the work that has been done by employees and is aimed at development [8]. In previous research, it was found that there was a positive and significant influence between job performance appraisals on performance, but there was a research gap in research (Ibnu \& Syaharuddin, 2016) which found no influence between job performance appraisals on employee performance [9]. This study will examine the effect of competency-based HR management and job performance assessments on the village apparatus's performance in Batubulan.

\section{Method}

This research design is a type of quantitative research using a paradigm positivist, which refers to the study of rational, empirical principles. using measured data obtained from filling out questionnaires by respondents. The purpose of this study is to measure the causal relationship between variables. The exogenous variables of this study are Competency-based HR Management $\left(\mathrm{X}_{1)}\right.$ and Performance Assessment $\left(\mathrm{X}_{2}\right)$. at the same time, the endogenous variable is the Village performance $(\mathrm{Y})$. The research design used was quantitative research design, and in this research, the design used SPSS, namely hypothesis testing using the F test and t-test. The research location is in the village office of Batubulan, and the population is Batubulan Village apparatus and uses a saturated sample, namely using the entire population as the sample.

Types of data sources are primary, namely by interviewing and distributing questionnaires, and secondary, by using data obtained from the Batubulan village office. Some of the tests carried out in this study were validity and reliability tests for testing the research instruments, while hypothesis testing was using the statistical t-test and F test. An instrument's validity can be seen from the correlation coefficient value between the item score and the total score. Validity testing is done using Pearson Product Moment correlation with a correlation coefficient $\geq$ of 0.3 (cut off $\geq 0.3$ ). The reliability test of this research instrument uses the value Cronbach Alpha. Cronbach Alpha's value is reliable if the value is greater than or equal to 0.7 (Supriyadi, 2014). Hypothesis testing is done by using the t-test for the partial effect hypothesis testing is done by using the t-test, if obtained $p$-value, it $<0.05$ (alpha 5\%) means significant and uses the $\mathrm{F}$ test to answer the hypothesis of the effect of the independent variable on the dependent variable partially. The research hypotheses in this study are: 
$\mathbf{H}_{1}$ : Competency-based HR management has a positive and significant effect on the performance of the Batubulan Village Apparatus

$\mathbf{H}_{2}$ : Assessment of work performance has a positive and significant effect on the Batubulan Village apparatus's performance.

H3: Competency-based HR management and work performance assessment together have a positive and significant effect on the Batubulan Village apparatus's performance.

\section{Results and Discussion}

After assessing the reliability and validity, all question items in the questionnaire were declared valid and reliable. The results of calculations using SPSS show that the correlation coefficient is $\geq 0.3$, while for reliability, the Cronbach's Alpha value for each variable is more significant than 0.70 , which is 0.938 . The model summary table shows an R of 0.801 , which means the magnitude of the correlation between the Competency-based HR management system and job performance appraisals on village staff's performance. Meanwhile, R Square's value is 0.642 , which means that the contribution of competency-based HR management and work performance appraisals to performance is in the percentage of $64.2 \%$ of village staff. Other variables influence the rest: not examined in this study.

Table 1.1

Coefficient R Square

\begin{tabular}{ccccc}
\hline Model & $\mathrm{R}$ & $\mathrm{R}$ Square & $\begin{array}{c}\text { Adjusted R } \\
\text { Square }\end{array}$ & $\begin{array}{c}\text { Std Error of the } \\
\text { Estimate }\end{array}$ \\
\hline 1 & .801 & .642 & .606 & 2.44794 \\
\hline
\end{tabular}

Table 1.2

Coefficient Anova

\begin{tabular}{llllll}
\hline Model & Sum of Square & df & Mean Square & F & Sig \\
\hline 1 Regression & 290.205 & 2 & 145.102 & 24.214 & $.000^{\mathrm{a}}$ \\
Residual & 161.795 & 27 & 5.992 & & \\
Total & 452.000 & 29 & & & \\
\hline
\end{tabular}

Table 1.2 shows the sig value of 0.000 , which is smaller than 0.05 , which means that ten independent variables, namely competency-based HR management and job performance appraisal, significantly affect the Batubulan Village apparatus's performance. 
Table 1.3

Effect, HR Management System, Based On Competency and Assessment Of Work Achievement on Performance

\begin{tabular}{|c|c|c|c|c|c|}
\hline \multirow[t]{2}{*}{ Model } & \multicolumn{2}{|c|}{ Unstandardized Coefficien } & $\begin{array}{c}\text { Standardized } \\
\text { Coefficient }\end{array}$ & $\mathrm{t}$ & Sig \\
\hline & $\mathrm{B}$ & Std. Error & Beta & & \\
\hline 1 (Constant) & .473 & 4,484 & & .106 & .917 \\
\hline $\mathrm{X} 1$ & .188 & .089 & .380 & 2.101 & .045 \\
\hline $\mathrm{X} 2$ & .452 & .173 & .471 & 2.607 & .015 \\
\hline
\end{tabular}

H$_{1}$ : Competency-based HR Management has a positive and significant effect on the performance of the Batubulan Village Apparatus

From the analysis results in table 1.3 , the sig value is 0.045 , which is smaller than 0.05 , and the $t$ table's value, namely $t$ count of $2.101>t$ table 2.05 . So that hypothesis $1\left(\mathrm{H}_{1}\right)$ is accepted. Namely, competency-based human resource management partially positively and significantly affects the Batupulan village apparatus's performance. The competence that can affect performance in this research is Cognitive Intelligence Competencies, Emotional Intelligence Competencies dan Social Intelligence Competencies.

$\mathbf{H}_{2}$ : Assessment of work performance has a positive and significant effect on the Batubulan Village apparatus's performance.

From the analysis results on the table, the sig value of 0.015 is smaller than 0.05 , and the value is higher than the $t$ table value, namely $t$ count $2.607>t$ count 2.05 . So until hypothesis 2 $\left(\mathrm{H}_{2}\right)$ is accepted, job performance appraisal positively and significantly affects the Batubulan Village apparatus's performance. The assessment of work performed in this study is work quality, work quantity, work relationship, leadership, knowledge, caution, diligence, work reliability, and initiative.

H3: Competency-based HR management and work performance assessment together positively and significantly affect the Batubulan Village apparatus

Table 1.2 analysis shows that the sig 0.000 value is smaller than 0.05 and the $F$ value The count is higher than the F table value, namely F count 24.214> from F table 3.35. So, hypothesis $2\left(\mathrm{H}_{3}\right)$ is accepted by Competency-based HR Management, and work performance assessment together has a positive and significant effect on the Batubulan Village apparatus's performance. This study's performance is quality, quantity, timeliness, effectiveness, the need for supervision, and interpersonal influence. 


\section{Conclusion}

The conclusion of this study is :

1. Competency-based HR Management has a positive and significant effect on the performance of the Batubulan Village Apparatus.

2. Assessment of work performance has a positive and significant effect on the performance of the Batubulan Village apparatus.

3. Competency-based HR management and work performance assessment together have a positive and significant effect on the Batubulan Village apparatus's performance.

The suggestions in this study are:

1. To improve village officials' performance in the recruitment process, village officials must pay attention to the competencies possessed by prospective village officials. The competencies referred to are cognitive abilities, emotional abilities, and social abilities. Conduct training for village officials who can improve the cognitive abilities of village officials.

2. We are conducting periodic work performance appraisals consisting of assessing work quality, work quantity, work relations, leadership, knowledge, caution, diligence, work reliability, and initiative. This assessment can encourage the improvement of village officials' performance.

\section{References}

[1] Duadji and Noverman:Manajemen Pelayanan Publik (Wacana Konsep, Teori dan Problema Pelayanan Publik). Bandar Lampung: Universitas Lampung, (2013).

[2] Mangkunegara, A. P.:Manajemen Sumber Daya Manusia: Cetakan Kesebelas, Sebelas. Bandung: PT. Remaja Rosdakarya, (2013).

[3] Mundarti, M.: Faktor-Faktor Yang Mempengaruhi Kinerja Dosen Dalam Melaksanakan Proses Belajar Mengajar Di Prodi Kebidanan Magelang Politeknik Kesehatan Semarang Tahun Ajaran 2005/2006, program Pascasarjana Universitas Diponegoro, (2007).

[4] Wibowo:Manajemen Kinerja, edisi kedua. Raja Grafindo Perkasa, (2017).

[5] Spencer, L. M. and Spencer, P. S. M.:Competence at work models for superior performance. Canada: John Wiley \& Sons, (2008).

[6] Ryan, G.Spencer, L. M.and Bernhard, U.: Development And Validation Of A Customized Competency-Based Questionnaire, Cross Cult. Manag. An Int. J., vol. 19, no. 1, pp. 90-103, (2012).

[7] Soeprihanto, J.:Penilaian kinerja dan pengembangan karyawan. Yogyakarta: BPFE, (2001).

[8] Malayu Hasibuan, S. P.:Manajemen Sumber Daya Manusia, Edisi Revisi. Jakarta: PT Bumi Aksara, (2002).

[9] Yamanie, I. Y. and Syaharuddin, Y.: Pengaruh Penilaian Prestasi Kerja, Komitmen Organisasi Dan Disiplin Kerja Terhadap Kinerja Karyawan Pada Pt. Pelabuhan Indonesia Iv Cabang Samarinda, J. Manaj., vol. 8, no. 1, pp. 55-65, (2016). 